\title{
DEKOMPOSISI DAUN DAN RANTING MANGIUM DAN EKALIPTUS OLEH DELAPAN ISOLAT FUNGI PELAPUK
}

\section{(Decomposition of Mangium and Eucalypt Leaves and Trigs by Eight Decaying Fungi Isolates)}

\author{
Oleh/By : \\ Djarwanto $^{1}$, Sihati Suprapti ${ }^{1} \&$ Ridwan Achmad Pasaribu ${ }^{1}$ \\ ${ }^{1}$ Pusat Penelitian dan Pengembangan Hasil Hutan, Jl. Gunung Batu, Bogor. \\ Telp. 0251-8633378, Fax. 0251-8633413
}

Diterima 11 Juni 2009, disetujui 30 Juni 2009

\begin{abstract}
Decomposition of sterilized leaves and twigs of mangium (Acacia mangium) and eucalypt (Eucalyptus sp.) using eight isolates of decaying fungi i.e. HHBI-204 (Schizophyllum commune), HHBI-302, HHBI-341, HHBI-346 to 350 was studied in laboratory after incubated for thirty days. Degradation rate was evaluated based on change of organic carbon, nitrogen, nutrient content, and cation exchange capacity (CEC). Results indicated that those fungi affected the chemical content changes of the samples. Ratio $C / N$ was around 24.3-33.4 for mangium and 19.527.6 for eucalypt. The lower $C / N$ ratios on mangium were obtained from samples inoculated by fungi number HHBI341, HHBI-346 and HHBI-350 i.e. 25.9; 25.0 and 24.3; and on eucalypt were obtained from samples inoculated by fungi number HHBI-302, HHBI-341, HHBI-346 and HHBI-350 i.e. 20.1; 19.8; 19.5 and 20.9, repectively. Nutrient contents on mangium were N 0.52-0.86\%; P 0.32-0.38\% and K 0.16-0.21\%; and on eucalypt were N0.66$0.94 \% ; P 0.32-0.38 \%$ and $\mathrm{K} 0.20-0.30 \%$. The CEC values of mangium and eucalypt were $23.48-28.71 \mathrm{me} / 100 \mathrm{~g}$ and $25.73-29.11$ me $/ 100 \mathrm{~g}$, respectively.
\end{abstract}

Keywords: Logging wastes, decaying fungi, decomposition, mycelial growth

\begin{abstract}
ABSTRAK
Studi dekomposisi daun dan ranting mangium (Acacia mangium) dan ekaliptus (Eucalyptus sp.) yang disterilkan, menggunakan delapan isolat fungi pelapuk yaitu HHBI-204 (Schizophyllum commune), HHBI302, HHBI-341, HHBI-346-350, dan diinkubasikan selama 30 hari secara laboratoris. Tingkat degradasi contoh uji dievaluasi berdasarkan perubahan kandungan karbon organik, nitrogen total, kadar unsur hara, dan kapasitas tukar kation (KTK). Hasilnya menunjukkan bahwa inokulasi fungi berpengaruh terhadap kandungan kimia contoh uji tersebut. Nisbah $\mathrm{C} / \mathrm{N}$ berkisar antara 24,3-33,4 (untuk mangium) dan 19,5-27,6 (untuk ekaliptus). Nisbah $\mathrm{C} / \mathrm{N}$ yang rendah dijumpai pada mangium yang diinokulasi HHBI-341, HHBI-346 dan HHBI-350 yaitu masing-masing 25,9; 25,0 dan 24,3; dan pada ekaliptus yang diinokulasi HHBI-302, HHBI-341, HHBI-346 dan HHBI-350 berturutturut yaitu 20,$1 ; 19,8 ; 19,5$ dan 20,9. Pada mangium, kandungan unsur hara berkisar antara: $\mathrm{N} 0,52-0,86 \%$; P 0,32$0,38 \%$ dan K 0,16- 0,21\%. Pada ekaliptus, kandungan unsurnya berkisar antara: N 0,66-0,94\%; P 0,32$0,38 \%$ dan kadar K 0,2-0,30\%. Nilai KTK contoh uji masing-masing adalah 23,48 - 28,71 me/100 g (mangium) dan 25,73-29,11 me/100 g (ekaliptus).
\end{abstract}

Kata kunci: Limbah pembalakan, fungi pelapuk, dekomposisi, pertumbuhan miselium 


\section{PENDAHULUAN}

Hutan tanaman industri (HTI) selain menghasilkan kayu bulat untuk bahan baku pulp juga menghasilkan limbah tebangan berupa kayu, ranting, daun/serasah dan kulit kayu. Muladi et al. (2001) menyatakan bahwa total biomasa kayu mangium (Acacia mangium) umur 5 7 tahun berkisar antara 60,469 - 95,846 ton/ha, dan total biomasa kayu leda/ekaliptus (Eucalyptus deglupta) umur 5 - 9 tahun berkisar antara 45,673 - 116,373 ton/ha. Sampai saat ini industri pulp hanya memanfaatkan kayu berdiameter $10 \mathrm{~cm}$ atau lebih. Kayu bulat jenis mangium dan ekaliptus yang berdiameter kurang dari $10 \mathrm{~cm}$ dapat mencapai $20 \%$ dari jumlah volume kayu yang diproduksi, masih merupakan limbah yang belum dimanfaatkan (Djarwanto et al. 2007). Menurut Anshori dan Supriyadi (2001), di HTI pulp mangium milik PT Musi Hutan Persada pada tebangan rotasi pertama (umur 9 tahun) dengan luas 193.500 hektar, diperoleh limbah berupa kulit kayu sebanyak 15,18 ton/ha, kayu residu tebangan 31,43 ton/ha, daun (serasah) 4,01 ton/ha dan tegakan mati sebanyak 5,84 ton/ha. Besarnya limbah yang belum termanfaatkan sebenarnya merupakan potensi kerugian karena untuk dapat memproduksi material kayu bahan baku pulp sebanyak volume biomassa limbah tersebut diperlukan biaya yang tidak sedikit dan waktu lama.

Daun dan ranting yang tertimbun dan secara alami lambat terdekomposisi, berpotensi menjadi sumber bahan kebakaran hutan. Penelitian ini bertujuan untuk mendapatkan fungi pelapuk, yang efektif mendekomposisi daun dan ranting mangium dan ekaliptus agar dapat dimanfaatkan sebagai penghara tanah pada areal HTI yang bersangkutan.

\section{BAHAN DAN METODE}

\section{A. Bahan}

Contoh uji daun dan ranting diambil dari areal hutan tanaman mangium di PT Musi Hutan Persada, Sumatera Selatan dan dari hutan tanaman ekaliptus di PT Toba Pulp Lestari, Sumatera Utara. Pengujian dekomposisi daun dan ranting mangium dan ekaliptus dilakukan secara laboratoris. Adapun fungi pelapuk yang diuji terdiri dari delapan isolat yaitu HHBI-204 (Schirophyllum commune), HHBI-302, HHBI-341, dan HHBI-346-350.

\section{B. Metode}

\section{Pembuatan contoh uji}

Contoh uji tersebut dibiarkan pada suhu kamar sampai mencapai kering udara kemudian digiling dengan chopper untuk mendapatkan partikel daun dan ranting yang lebih kecil. Contoh uji dilembabkan sampai mencapai kadar air 65\% dengan cara menambahkan air bersih. Kemudian dikemas dalam kantong plastik PVC tahan panas, masing-masing sebanyak 300 gram per kantong. Contoh uji disterilkan menggunakan autoklaf pada suhu $121^{\circ} \mathrm{C}$ dan tekanan 1,5 atmosfir selama 30 menit.

\section{Uji efektivitas fungi pelapuk}

Contoh uji steril yang telah dingin diinokulasi fungi penguji secara aseptis, kemudian diinkubasikan selama 30 hari (satu bulan). Setiap isolat fungi disediakan 5 ulangan. Parameter 
yang diamati yaitu pertumbuhan miselium dan kehilangan berat contoh uji yang diukur setiap minggu sampai umur 4 minggu. Pengamatan pertumbuhan miselium dilakukan dengan cara mengukur luas permukaan contoh uji yang ditumbuhi miselium dibagi luas keseluruhan permukaan dan dinyatakan dalam persen. Sedangkan kehilangan berat contoh uji diukur berdasarkan selisih berat awal dan akhir dibagi berat awal dan dinyatakan dalam persen.

\section{Analisa kimia}

Untuk keperluan analisa kimia contoh uji diambil dari 5 ulangan yang disediakan untuk setiap isolat kemudian dicampur dan diaduk agar merata. Analisa kimia dilakukan di Laboratorium Tanah dan Tanaman SEAMEO BIOTROP, Bogor. Tingkat pelapukan diukur melalui perbandingan kadar $\mathrm{C}$ dan $\mathrm{N}$ yang ditetapkan sebelum dan sesudah inkubasi. Penetapan rasio atau nisbah $\mathrm{C} / \mathrm{N}$ dilakukan dengan cara menetapkan karbon organik menurut Walkey and Black (1934) dalam Sukmana (1983) dan nitrogen total dengan metode Kjeldahl (Sukmana, 1983). Penetapan kadar kalsium (Ca), fosfor (P), kalium (K) dan magnesium (Mg), menggunakan Atomic Absorption Spectrophotometer (Jackson, 1958), dan kapasitas tukar kation (KTK) menggunakan cara volumetri atau titrimetri (Piper, 1947).

\section{Analisa data}

Analisis data kehilangan berat contoh uji (\%) pada masing-masing tingkatan umur inkubasi (minggu) digunakan rancangan acak lengkap ( 9 perlakuan isolat fungi termasuk kontrol) dengan lima ulangan. Jika dalam analisis berbeda nyata maka penelaahan dilanjutkan dengan uji Tukey (Steel \& Torrie, 1990).

\section{HASIL DAN PEMBAHASAN}

Kehilangan berat contoh uji daun dan ranting mangium yang dinokulasi fungi pelapuk tercantum pada Tabel 1. Pada taraf ini material daun dan ranting masih dapat dikenali bentuknya, namun sudah terjadi perubahan warna menjadi coklat kehitaman dan rapuh, serta bau kompos cukup kuat. Kehilangan berat terjadi akibat penguapan dan hasil fermentasi meningkat seiring dengan lamanya waktu inkubasi. Persentase kehilangan berat pada daun dan ranting ekaliptus lebih rendah dibandingkan dengan pada daun dan ranting mangium (Tabel 1). Hal tersebut diduga disebabkan oleh kandungan minyak atsiri, dicirikan oleh aroma minyak kayu putih yang masih cukup kuat sampai satu bulan setelah daun ekaliptus diinokulasi fungi.

Analisis statistik menunjukkan bahwa inokulasi fungi mempengaruhi penyusutan bobot contoh uji $(\mathrm{p} \leq 0.01)$. Hasil uji beda Tukey $(\mathrm{p} \leq 0.05)$ menunjukkan bahwa persentase kehilangan berat pada daun dan ranting mangium dan ekaliptus terendah dihasilkan pada kontrol. Hal ini mungkin disebabkan kehilangan berat pada kontrol hanya disebabkan oleh pengaruh penguapan air. Lama waktu inkubasi berpengaruh pada kehilangan berat contoh. Kehilangan berat yang rendah dijumpai pula pada ekaliptus yang diinokulasi HHBI-204, HHBI-302, dan HHBI-350 pada umur inkubasi 4 minggu (Tabel 1). Kehilangan berat tertinggi diperoleh pada contoh uji yang diinokulasi HHBI-349, (masing-masing pada daun dan ranting mangium pada umur inkubasi 1, 2, 3 dan 4 minggu dan daun dan ranting ekaliptus 
pada umur inkubasi 1 dan 2 minggu). Hal ini membuktikan bahwa aktivitas HHBI-349 paling tinggi dalam mendekomposisi contoh uji. Kehilangan berat yang tinggi pada umur inkubasi 4 minggu dijumpai pula pada mangium yang diinokulasi HHBI-204, HHBI-302, HHBI-346, HHBI-347 dan HHBI-348, dan ekaliptus yang diinokulasi HHBI-341 dan HHBI-346. Ini membuktikan bahwa fungi tersebut memiliki aktivitas yang tinggi dalam mendekomposisi lignoselulosa, dan aktivitasnya tidak menunjukkan perbedaan yang nyata dengan HHBI-349 (Tabel 1).

Tabel1. Rata-rata persentase kehilangan berat daun dan ranting mangium dan ekaliptus setelah diinkubasi

Table 1. The average weight loss percentage of mangium and eucalypt leaves and twigs after incubated

\begin{tabular}{|l|l|l|l|l|l|c|c|c|}
\hline \multirow{2}{*}{$\begin{array}{c}\text { Isolat fungi } \\
\text { (Fungal isolate) }\end{array}$} & \multicolumn{7}{|c|}{$\begin{array}{c}\text { Kehilangan berat (\%) pada umur inkubasi (minggu) } \\
\text { (Weight loss(\%) at the age of incubation (week/s)) }\end{array}$} \\
\cline { 2 - 11 } & \multicolumn{7}{|c|}{ Mangium (Mangium) } & \multicolumn{3}{c|}{ Ekaliptus (Eucalypt) } \\
\hline HHBI-204 & $0,62 \mathrm{ab}$ & $1,64 \mathrm{ab}$ & $2,39 \mathrm{a}$ & $3,22 \mathrm{a}$ & $0,52 \mathrm{ab}$ & $0,94 \mathrm{ab}$ & $1,28 \mathrm{ab}$ & $1,88 \mathrm{~b}$ \\
\hline HHBI-302 & $0,46 \mathrm{ab}$ & $1,25 \mathrm{bc}$ & $1,66 \mathrm{bc}$ & $2,99 \mathrm{a}$ & $0,62 \mathrm{ab}$ & $0,99 \mathrm{ab}$ & $1,26 \mathrm{ab}$ & $1,77 \mathrm{~b}$ \\
\hline HHBI-341 & $0,72 \mathrm{ab}$ & $1,64 \mathrm{ab}$ & $2,18 \mathrm{abc}$ & $2,66 \mathrm{ab}$ & $0,98 \mathrm{a}$ & $1,42 \mathrm{a}$ & $1,79 \mathrm{a}$ & $2,46 \mathrm{a}$ \\
\hline HHBI-346 & $0,96 \mathrm{ab}$ & $1,98 \mathrm{a}$ & $2,31 \mathrm{ab}$ & $2,96 \mathrm{a}$ & $0,75 \mathrm{ab}$ & $1,22 \mathrm{ab}$ & $1,62 \mathrm{ab}$ & $2,55 \mathrm{a}$ \\
\hline HHBI-347 & $0,54 \mathrm{ab}$ & $1,55 \mathrm{ab}$ & $2,31 \mathrm{ab}$ & $3,05 \mathrm{a}$ & $0,86 \mathrm{ab}$ & $1,27 \mathrm{ab}$ & $1,57 \mathrm{ab}$ & $2,18 \mathrm{ab}$ \\
\hline HHBI-348 & $0,89 \mathrm{ab}$ & $1,63 \mathrm{ab}$ & $2,45 \mathrm{a}$ & $3,24 \mathrm{a}$ & $0,77 \mathrm{ab}$ & $1,20 \mathrm{ab}$ & $1,51 \mathrm{ab}$ & $2,14 \mathrm{ab}$ \\
\hline HHBI-349 & $1,05 \mathrm{a}$ & $1,83 \mathrm{a}$ & $2,52 \mathrm{a}$ & $3,29 \mathrm{a}$ & $0,92 \mathrm{a}$ & $1,38 \mathrm{a}$ & $1,67 \mathrm{ab}$ & $2,19 \mathrm{ab}$ \\
\hline HHBI-350 & $0,51 \mathrm{ab}$ & $1,26 \mathrm{bc}$ & $2,05 \mathrm{abc}$ & $2,88 \mathrm{ab}$ & $0,66 \mathrm{ab}$ & $1,11 \mathrm{ab}$ & $1,39 \mathrm{ab}$ & $1,94 \mathrm{~b}$ \\
\hline $\begin{array}{l}\text { Kontrol } \\
\text { (Controb) }\end{array}$ & $0,38 \mathrm{~b}$ & $1,13 \mathrm{c}$ & $1,60 \mathrm{c}$ & $2,12 \mathrm{~b}$ & $0,41 \mathrm{~b}$ & $0,87 \mathrm{~b}$ & $1,17 \mathrm{~b}$ & $1,71 \mathrm{~b}$ \\
\hline
\end{tabular}

Keterangan (Remarks): Angka-angka dalam masing-masing kolom yang diikuti oleh huruf sama tidak berbeda nyata pada uji Tukey $\mathrm{p} \leq 0.05$ (The numbers within each column followed by the same letter, means non-significantly different, Tukey test $p \leq 0.05$ )

Pertumbuhan miselium di permukaan contoh uji daun dan ranting mangium dan ekaliptus disajikan pada Tabel 2. Pada daun dan ranting mangium, pertumbuhan miselium telah nampak pada minggu pertama, dan umumnya telah memenuhi permukaan contoh uji pada umur satu bulan setelah inkulasi. Pada umur 4 minggu setelah inokulasi, pertumbuhan miselium HHBI-302 hanya mencapai 17,86\%. Hal ini mungkin miselium belum muncul ke permukaan contoh, atau mungkin miselium yang tumbuh sangat tipis sehingga sulit dilihat dengan mata telanjang. Pertumbuhan miselium pada daun dan ranting ekaliptus berlangsung lambat sejak minggu pertama sampai minggu keempat. Hanya satu jenis fungi yaitu HHBI346 yang pertumbuhan miseliumnya mencapai seluruh permukaan contoh. Hal ini mungkin disebabkan oleh adanya minyak atsiri yang terdapat dalam contoh uji sehingga menghambat pertumbuhan miselium fungi tersebut. 
Tabel2. Persentase pertumbuhan miselium di permukaan daun dan ranting mangium dan ekaliptus setelah diinkubasikan selama 4 minggu

Table 2. Percentage of mycelium growth on surface of mangium and eucalypt leaves and twigs after 4 weeks incubation

\begin{tabular}{|l|c|c|c|c|c|c|c|c|}
\hline \multirow{2}{*}{$\begin{array}{c}\text { Isolat fungi } \\
\text { (Fungal isolate) }\end{array}$} & \multicolumn{7}{|c|}{$\begin{array}{c}\text { Pertumbuhan miselium pada umur inkubasi (Mycelium growth on the age of } \\
\text { incubation), \%/minggu (\% / week) }\end{array}$} \\
\cline { 2 - 10 } & 1 & 2 & 3 & 4 & 1 & 2 & 3 & 4 \\
\hline & 7,6 & 15,3 & 76,6 & 100 & 0,0 & 5,3 & 36,3 & 85,4 \\
\hline HHBI-204 & 4,7 & 9,3 & 13,6 & 17,9 & 1,7 & 6,3 & 10,6 & 12,9 \\
\hline HHBI-302 & 17,7 & 35,4 & 100 & 100 & 2,7 & 8,4 & 13,6 & 20,2 \\
\hline HHBI-341 & 25,2 & 50,4 & 100 & 100 & 8,4 & 45,1 & 100 & 100 \\
\hline HHBI-346 & 10,5 & 21,0 & 91,0 & 99,0 & 1,5 & 9,8 & 29,1 & 58,4 \\
\hline HHBI-347 & 11,5 & 23,0 & 74,1 & 99,3 & 0,0 & 4,5 & 14,1 & 49,2 \\
\hline HHBI-348 & 16,8 & 33,6 & 52,1 & 69,3 & 0,0 & 1,6 & 5,2 & 9,3 \\
\hline HHBI-349 & 5,4 & 10,7 & 60,7 & 95,7 & 0,0 & 1,7 & 6,7 & 15,7 \\
\hline HHBI-350 & & & & & & & & \\
\hline
\end{tabular}

Keterangan (Remarks): Angka menunjukkan persentase pertumbuhan miselium rata-rata dari lima ulangan (Number represent the average of mycelium growth of five replicates).

Data kandungan unsur hara yang terdapat dalam daun dan ranting mangium dan ekaliptus disajikan pada Tabel 3 dan 4. Nisbah $\mathrm{C} / \mathrm{N}$ pada contoh daun dan ranting mangium dan ekaliptus segar masing-masing adalah 69,8 dan 77,0. Nisbah $\mathrm{C} / \mathrm{N}$ contoh uji yang diinokulasi fungi pelapuk masing-masing berkisar antara 24,3-33,4 (mangium) dan 19,5-27,6 (ekaliptus). Nisbah $\mathrm{C} / \mathrm{N}$ yang rendah dijumpai pada mangium yang diinokulasi HHBI-341, HHBI-346 \& HHBI-350 yaitu masing-masing 25,9; 25,0 dan 24,3. Nilai C/N mangium tersebut lebih tinggi dari pada standar kompos Perhutani yaitu $<20$ (Anonimus, 1979 dalam Mindawati et al., 1998), namun memenuhi standar kompos Jepang yaitu <35 (Harada, 1993 dalam Mindawati et al., 1998) dan kompos menurut Bidlingmaier (1993) dalam Gunadi (1996) yaitu $<24,2$. Sedangkan nisbah $\mathrm{C} / \mathrm{N}$ ekaliptus memenuhi kompos Perhutani, Jepang dan kompos menurut Bidlingmaier. 
Tabel 3. Kandungan unsur hara pada daun dan ranting mangium setelah diinkubasikan selama 30 hari

Table 3. Nutrient content in mangium leaves and twigs after incubated for thirty days

\begin{tabular}{|c|c|c|c|c|c|c|c|}
\hline $\begin{array}{c}\text { Isolat fungi } \\
\text { (Fungal isolate) }\end{array}$ & $\begin{array}{c}\text { C organik } \\
\text { (Organic C) } \\
(\%)\end{array}$ & $\begin{array}{c}\mathrm{N} \text { total } \\
(\text { Total } \mathrm{N}) \\
(\%)\end{array}$ & $\begin{array}{c}\mathrm{C} / \mathrm{N} \\
\text { ratio }\end{array}$ & $\begin{array}{c}\mathrm{P}_{2} \mathrm{O}_{5} \\
(\%)\end{array}$ & $\begin{array}{c}\mathrm{CaO} \\
(\%)\end{array}$ & $\begin{array}{c}\mathrm{MgO} \\
(\%)\end{array}$ & $\begin{array}{c}\mathrm{K}_{2} \mathrm{O} \\
(\%)\end{array}$ \\
\hline HHBI-204 & 17,26 & 0,64 & 27,0 & 0,27 & 0,21 & 0,09 & 0,16 \\
\hline HHBI-302 & 18,64 & 0,61 & 30,6 & 0,28 & 0,21 & 0,09 & 0,16 \\
\hline HHBI-341 & 13,48 & 0,52 & 25,9 & 0,29 & 0,19 & 0,11 & 0,18 \\
\hline HHBI-346 & 21,48 & 0,86 & 25,0 & 0,27 & 0,18 & 0,08 & 0,16 \\
\hline HHBI-347 & 22,41 & 0,67 & 33,4 & 0,31 & 0,23 & 0,12 & 0,19 \\
\hline HHBI-348 & 21,39 & 0,64 & 33,4 & 0,29 & 0,19 & 0,13 & 0,18 \\
\hline HHBI-349 & 19,56 & 0,68 & 28,8 & 0,27 & 0,24 & 0,15 & 0,19 \\
\hline HHBI-350 & 17,52 & 0,72 & 24,3 & 0,27 & 0,21 & 0,08 & 0,21 \\
\hline $\begin{array}{c}\text { Kontrol } \\
\text { (Control) }\end{array}$ & 19,83 & 0,74 & 26,8 & 0,31 & 0,21 & 0,12 & 0,21 \\
\hline $\begin{array}{c}\text { Daun dan } \\
\text { ranting segar } \\
\text { (Fresh leaf and } \\
\text { twig) }\end{array}$ & 32,82 & 0,47 & 69,8 & 0,19 & 0,19 & 0,26 & 0,43 \\
\hline
\end{tabular}

Nisbah C/N yang rendah dijumpai pada ekaliptus yang diinokulasi HHBI-302, HHBI-341, HHBI-346 dan HHBI-350 berturut-turut yaitu 20,1; 19,8; 19,5 dan 20,9, sehingga nisbah $\mathrm{C} / \mathrm{N}$-nya memenuhi standar kompos Perhutani. Hal ini mungkin semakin lama penyimpanan daun dan ranting mangium dan ekaliptus dapat menurunkan nilai tersebut. Selain itu, mungkin disebabkan ukuran partikel daun dan ranting tersebut lebih kecil, dan perlakuan sterilisasi dapat menurunkan nilai nisbah $\mathrm{C} / \mathrm{N}$ tersebut. Selain itu, perbedaan nisbah C/N mangium dengan standar Perhutani mungkin disebabkan oleh bahan baku utama dan aktivator serta metode yang digunakan berbeda. 
Tabel 4. Kandungan unsur hara pada daun dan ranting ekaliptus setelah inkubasi selama 30 hari

Table 4. Nutrient content in eucalypt leaves and twigs after incubated for thirty days

\begin{tabular}{|c|c|c|c|c|c|c|c|}
\hline $\begin{array}{c}\text { Isolat fungi } \\
\text { (Fungal isolate) }\end{array}$ & $\begin{array}{c}\text { C organik } \\
(\text { Organic C) } \\
(\%)\end{array}$ & $\begin{array}{c}\mathrm{N} \text { total } \\
(\text { Total } \mathrm{N}) \\
(\%)\end{array}$ & $\begin{array}{c}\mathrm{C} / \mathrm{N} \\
\text { ratio }\end{array}$ & $\begin{array}{c}\mathrm{P}_{2} \mathrm{O}_{5} \\
(\%)\end{array}$ & $\begin{array}{c}\mathrm{CaO} \\
(\%)\end{array}$ & $\begin{array}{c}\mathrm{MgO} \\
(\%)\end{array}$ & $\begin{array}{c}\mathrm{K}_{2} \mathrm{O} \\
(\%)\end{array}$ \\
\hline HHBI-204 & 14,63 & 0,69 & 21,2 & 0,31 & 0,24 & 0,12 & 0,21 \\
\hline HHBI-302 & 16,23 & 0,81 & 20,1 & 0,34 & 0,24 & 0,16 & 0,21 \\
\hline HHBI-341 & 13,05 & 0,66 & 19,8 & 0,32 & 0,21 & 0,16 & 0,24 \\
\hline HHBI-346 & 18,29 & 0,94 & 19,5 & 0,33 & 0,26 & 0,14 & 0,23 \\
\hline HHBI-347 & 19,85 & 0,72 & 27,6 & 0,35 & 0,29 & 0,16 & 0,26 \\
\hline HHBI-348 & 18,38 & 0,80 & 23,0 & 0,34 & 0,26 & 0,15 & 0,18 \\
\hline HHBI-349 & 17,27 & 0,76 & 22,7 & 0,36 & 0,30 & 0,18 & 0,24 \\
\hline HHBI-350 & 16,28 & 0,78 & 20,9 & 0,38 & 0,28 & 0,16 & 0,26 \\
\hline Kontrol (Control) & 19,04 & 0,77 & 24,7 & 0,34 & 0,27 & 0,17 & 0,22 \\
\hline $\begin{array}{c}\text { Daun dan ranting } \\
\text { segar (Fresh leaf } \\
\text { and twig) }\end{array}$ & 34,67 & 0,45 & 77,0 & 0,17 & 0,24 & 0,29 & 0,47 \\
\hline
\end{tabular}

Unsur hara makro yang terdapat pada mangium tersebut antara lain $\mathrm{N}, \mathrm{P}\left(\mathrm{P}_{2} \mathrm{O}_{5}\right.$ total $), \mathrm{Ca}$ ( $\mathrm{CaO}), \mathrm{Mg}(\mathrm{MgO})$ dan $\mathrm{K}\left(\mathrm{K}_{2} \mathrm{O}\right.$ total) umumnya rendah. Unsur hara pada contoh uji yang diinokulasi fungi tersebut masing-masing adalah $\mathrm{N} 0,52-0,86 \%$, P 0,32-0,38\%, Ca 0,180,24\%, Mg 0,08-0,15\%, dan K 0,16-0,21\%. Unsur N, P dan Ca tersebut lebih tinggi dan unsur $\mathrm{Mg}$ dan K lebih rendah jika dibandingkan dengan mangium segar yaitu N 0,47\%, P 0,19\%, Ca $0,19 \%, \operatorname{Mg~0,26\% }$, dan K 0,43\%. Demikian pula, unsur hara ekaliptus yang diinokulasi fungi tersebut masing-masing yaitu N 0,66-0,94\%, P 0,32-0,38\%, Ca 0,21-0,30\%, Mg 0,12-0,18\%, K 0,21-0,30\%. Unsur N, P dan Ca tersebut lebih tinggi dan unsur Mg dan K lebih rendah jika dibandingkan dengan contoh ekaliptus segar yaitu N 0,45\%, P 0,17\%, Ca 0,24\%, Mg 0,29\%, dan K 0,47\%. Kadar N, P, K contoh uji mangium dan ekaliptus tersebut mendekati kandungan unsur hara pupuk kandang sapi, kuda dan domba yang dilaporkan oleh Hardjowigeno (1995) dalam Novizan (2002) yaitu N 0,3-0,6\%, P 0,2-0,3\% dan K 0,2-0,3\%. Kandungan nitrogen tersebut termasuk kriteria tinggi berdasarkan kriteria Pusat Penelitian Tanah yaitu 0,51-0,75\% (Novizan, 2002).

Kandungan unsur hara di dalam kompos sangat bervariasi tergantung jenis bahan baku yang digunakan dan cara pembuatan kompos. Kandungan unsur hara kompos menurut Novizan (2002) tersebut yaitu N 0,1-0,6\%, P 0,1-0,4\%, Ca 0,8-1,5\% dan K 0,8-1,5\%. Unsur hara contoh uji mangium dan ekaliptus yaitu $\mathrm{N}$ umumnya lebih tinggi, P memenuhi dan $\mathrm{Ca}, \mathrm{K}$ lebih rendah dibandingkan dengan unsur hara kompos Novizan tersebut.

Hasil analisa kimia kapasitas tukar kation (KTK) dan pengukuran derajad keasaman $(\mathrm{pH})$ daun dan ranting mangium dan ekaliptus dapat dilihat pada Tabel 5. Besar nilai $\mathrm{pH}$ ratarata contoh uji berkisar antara 6,5-7,1 atau netral, sama dengan $\mathrm{pH}$ tanah secara umum, yaitu 6-7 (Novisan, 2002). Sedangkan pH daun dan ranting segar adalah 5,9-6,0. Nilai pH tersebut memenuhi standar kompos Jepang yaitu 5,5-7,5 (Harada, 1993 dalam Mindawati et al., 1998) 
dan kompos menurut Bidlingmaier $\mathrm{pH}$ 6,6-8,2. Pada $\mathrm{pH}$ tersebut pertumbuhan tanaman umumnya berlangsung baik. Hal itu menunjukkan bahwa dari segi keasaman lingkungan mikro maka limbah pembalakan terutama daun dan ranting mangium dan ekaliptus yang melalui proses fermentasi cukup aman terhadap akar tanaman.

Nilai kapasitas tukar kation (KTK) berhubungan erat dengan tingkat kesuburan yang berpengaruh terhadap pertumbuhan tanaman. Pengaruh inokulasi fungi dan lama waktu inkubasi daun dan ranting cenderung dapat meningkatkan nilai KTK contoh uji masingmasing berkisar antara 23,48 - 28,71 me/100 g (mangium) dan 25,73 - 29,11 me/100 g (ekaliptus). Nilai KTK tersebut lebih tinggi jika dibandingkan dengan daun dan ranting segar yaitu 19,26 me/100 g pada mangium dan 20,08 me/100 g pada ekaliptus segar (Tabel 5). Nilai KTK tersebut memenuhi persyaratan kompos WHO yaitu $>20$ me/100 g (Rina et al., 2002 dalam Komarayati dan Pasaribu, 2005), dan termasuk kriteria sedang (17 - 24 me/100 g) sampai tinggi (25 - 40 me/100 g) menurut Pusat Penelitian Tanah (1983) dalam Novizan (2002). Nilai KTK yang tinggi tersebut dapat meningkatkan daya serap, daya simpan dan ketersediaan unsur hara yang dibutuhkan tanaman. KTK ini berhubungan erat dengan tingkat kesuburan tanah. Kadar air mangium umumnya lebih tinggi dibandingkan dengan kadar air ekaliptus (Tabel 5). Pada kadar air tersebut proses dekomposisi contoh uji oleh fungi tersebut masih berlangsung. Schmidt (2007) menyatakan bahwa kadar air optimum yang diperlukan oleh berbagai species pelapuk kayu bervariasi antara 36-210\%.

Tabel 5. Hasil analisis daun dan ranting mangium dan ekaliptus yang diinokulasi fungi

Table 5. Analytical results of mangium and eucalypt leaves and twigs inoculated by fungi

\begin{tabular}{|c|c|c|c|c|c|c|}
\hline \multirow{2}{*}{$\begin{array}{c}\text { Isolat fungi } \\
\text { (Fungal isolate) }\end{array}$} & \multicolumn{3}{|c|}{ Mangium (Mangium) } & \multicolumn{3}{c|}{ Ekaliptus (Eucalypt) } \\
\cline { 2 - 7 } & $\mathrm{pH}$ & $\begin{array}{c}\text { Nilai KTK } \\
\text { (Cation exchange } \\
\text { rate) (me/100 g }\end{array}$ & $\begin{array}{c}\text { Kadar air } \\
\text { (Moisture } \\
\text { content) }(\%)\end{array}$ & $\mathrm{pH}$ & $\begin{array}{c}\text { Nilai KTK } \\
\text { (Cation exchange } \\
\text { rate) }(\mathrm{me} / 100 \mathrm{~g})\end{array}$ & $\begin{array}{c}\text { Kadar air } \\
\text { (Moisture } \\
\text { content) }(\%)\end{array}$ \\
\hline HHBI-204 & 6,6 & 28,71 & 45,81 & 7,0 & 28,63 & 38,46 \\
\hline HHBI-302 & 7,1 & 27,23 & 51,26 & 7,1 & 28,63 & 39,71 \\
\hline HHBI-341 & 6,5 & 26,51 & 51,62 & 6,8 & 27,12 & 39,14 \\
\hline HHBI-346 & 6,7 & 24,55 & 49,19 & 6,9 & 27,14 & 40,45 \\
\hline HHBI-347 & 7,1 & 26,14 & 54,47 & 7,0 & 27,46 & 42,66 \\
\hline HHBI-348 & 7,0 & 23,48 & 45,62 & 6,8 & 26,18 & 39,75 \\
\hline HHBI-349 & 6,8 & 23,61 & 48,71 & 6,8 & 26,3 & 41,55 \\
\hline HHBI-350 & 6,8 & 24,52 & 47,16 & 6,9 & 25,73 & 42,17 \\
\hline $\begin{array}{c}\text { Kontrol } \\
\text { (Control) }\end{array}$ & 6,7 & 27,66 & 45,28 & 7,1 & 29,11 & 40,66 \\
\hline $\begin{array}{c}\text { Daun dan } \\
\text { ranting segar } \\
\text { (Fresh leaf and } \\
\text { twig) }\end{array}$ & 5,9 & 19,26 & 54,52 & 6,0 & 20,08 & 46,84 \\
\hline
\end{tabular}

Keterangan (Remarks): KTK = Kapasitas tukar kation (cation exchange rate) 
Logam berat yang terdapat dalam daun dan ranting mangium dan ekaliptus yang diinokulasi fungi setelah diinkubasikan selama 30 hari dapat dilihat pada Tabel 6. Kandungan logam berat tersebut antara lain $\mathrm{Pb}, \mathrm{Hg}$ dan $\mathrm{Cd}$ yang relatif rendah sehingga tidak terukur; dengan demikian dapat diasumsikan akan aman terhadap lingkungan. Kandungan logam tersebut rendah dari kandungan logam kompos Bidlingmaier (1993) dalam Gunadi (1996) yaitu $\mathrm{Pb} 250$ - $1.350 \mathrm{mg} / \mathrm{kg}, \mathrm{Hg} 0,4-9 \mathrm{mg} / \mathrm{kg}$, dan Cd 1,9 - $12 \mathrm{mg} / \mathrm{kg}$.

\section{Tabel 6. Kandungan logam berat pada daun dan ranting mangium dan ekaliptus} Table 6. Mineral content of mangium and eucalypt leaves and twigs

\begin{tabular}{|c|c|c|c|c|c|c|}
\hline \multirow{2}{*}{$\begin{array}{c}\text { Isolat fungi } \\
\text { Fungal isolate) }\end{array}$} & \multicolumn{3}{|c|}{ Mangium (Mangium) } & \multicolumn{3}{c|}{ Ekaliptus (Eucalypt) } \\
\cline { 2 - 7 } & $\mathrm{Pb}(\mathrm{ppm})$ & $\mathrm{Hg}(\mathrm{ppm})$ & $\mathrm{Cd}(\mathrm{ppm})$ & $\mathrm{Pb}(\mathrm{ppm})$ & $\mathrm{Hg}(\mathrm{ppm})$ & $\mathrm{Cd}(\mathrm{ppm})$ \\
\hline HHBI-204 & 0,02 & $\mathrm{tu}$ & 0,01 & $\mathrm{tu}$ & $\mathrm{tu}$ & $\mathrm{tu}$ \\
\hline HHBI-302 & $\mathrm{tu}$ & $\mathrm{tu}$ & $\mathrm{tu}$ & $\mathrm{tu}$ & $\mathrm{tu}$ & $\mathrm{tu}$ \\
\hline HHBI-341 & 0,02 & $\mathrm{tu}$ & 0,01 & $\mathrm{tu}$ & $\mathrm{tu}$ & $\mathrm{tu}$ \\
\hline HHBI-346 & $\mathrm{tu}$ & $\mathrm{tu}$ & $\mathrm{tu}$ & $\mathrm{tu}$ & $\mathrm{tu}$ & $\mathrm{tu}$ \\
\hline HHBI-347 & $\mathrm{tu}$ & $\mathrm{tu}$ & $\mathrm{tu}$ & $\mathrm{tu}$ & $\mathrm{tu}$ & $\mathrm{tu}$ \\
\hline HHBI-348 & $\mathrm{tu}$ & $\mathrm{tu}$ & 0,01 & $\mathrm{tu}$ & $\mathrm{tu}$ & $\mathrm{tu}$ \\
\hline HHBI-349 & 0,01 & $\mathrm{tu}$ & 0,01 & $\mathrm{tu}$ & $\mathrm{tu}$ & $\mathrm{tu}$ \\
\hline HHBI-350 & 0,01 & $\mathrm{tu}$ & 0,01 & $\mathrm{tu}$ & $\mathrm{tu}$ & $\mathrm{tu}$ \\
\hline $\begin{array}{c}\text { Kontrol } \\
\text { (Control) }\end{array}$ & 0,01 & $\mathrm{tu}$ & $\mathrm{tu}$ & $\mathrm{tu}$ & $\mathrm{tu}$ & $\mathrm{tu}$ \\
\hline $\begin{array}{c}\text { Daun dan } \\
\text { ranting segar } \\
\text { (Fresh leaf and } \\
\text { twig) }\end{array}$ & $\mathrm{tu}$ & $\mathrm{tu}$ & 0,2 & 0,08 & $\mathrm{tu}$ & 0,1 \\
\hline
\end{tabular}

Keterangan (Remarks): tu = tak terukur (unmeasured)

Dari hasil analisa unsur hara, nisbah $\mathrm{C} / \mathrm{N}$ dan nilai KTK menunjukkan bahwa setelah diinkubasikan selama 30 hari dengan menggunakan aktivator fungi pelapuk dapat meningkatkan kesuburan tanah sebagai soil conditioner. Meskipun peran fungi tersebut sebagai aktivator dekomposisi daun dan ranting baik pada mangium dan ekaliptus belum berpengaruh nyata. Kondisi tersebut memberikan isyarat bahwa proses pelapukan daun dan ranting oleh fungi penguji berjalan lambat. Komponen kimia kayu dirombak oleh fungi secara hidrolisis menggunakan ensim lignoselulase, menghasilkan senyawa sederhana yang dapat larut dalam air (Browning, 1967; Fengel and Wegener, 1984). Untuk daerah yang berbukit atau berupa lereng proses pelapukan yang lambat tersebut justru dapat menguntungkan karena unsur hara yang telah terdegradasi dari material daun dan ranting yang umumnya mudah larut air masih tertahan di dalam bahan dan akan terlepas ke alam (tanah) sedikit demi sedikit, sehingga jika terjadi hujan deras atau banjir unsur yang dibutuhkan tanaman tersebut tidak hilang terbawa arus air. Selain sebagai simpanan atau cadangan unsur hara, limbah pembalakan di lapangan dapat dipakai sebagai alas jalan kendaraan berat ketika melakukan evakuasi kayu, agar tidak terjadi pemadatan tanah secara berlebihan. Sehingga lahan mudah diolah kembali untuk ditanami pohon pada daur selanjutnya. 


\section{KESIMPULAN}

Pertumbuhan miselium fungi umumnya telah memenuhi permukaan contoh mangium pada umur 4 minggu setelah inokulasi dan hanya pertumbuhan fungi HHBI-346 yang telah memenuhi permukaan contoh eukaliptus. Inokulasi fungi meningkatkan penyusutan bobot contoh uji. Pada umur inkubasi 4 minggu kehilangan berat contoh uji akibat aktivitas fungi berkisar antara 2,12-3,29\% (mangium) dan 1,71-2,55\% (eukaliptus). Kehilangan berat terendah dijumpai pada kontrol (tanpa inokulasi fungi).

Nisbah C/N contoh uji yang diinokulasi delapan isolat fungi 24,3-33,4 (mangium) dan 19,5-27,6 (ekaliptus). Nisbah C/N yang rendah dijumpai pada contoh uji yang diinokulasi fungi HHBI-341, HHBI-346, dan HHBI-350. Pada mangium kandungan unsur hara masingmasing berkisar antara: N 0,52-0,86\%, P 0,32-0,38\%, Ca 0,18-0,24\%, dan Mg 0,08-0,15\%, K 0,16-0,21\% Demikian pula, pada ekaliptus kandungan unsur hara berkisar antara: N 0,660,94\%, P 0,32-0,38\%, Ca 0,21-0,30\%, Mg 0,12-0,18\%, K 0,21-0,30\%. Nilai KTK pada daun dan ranting yang di inokulasi fungi masing-masing adalah 23,48 - 28,71 me/100 g (mangium) dan 25,73 - 29,11 me/100 g (ekaliptus).

\section{DAFTAR PUSTAKA}

Anshori, S. and B. Supriyadi. 2001. Potency and management of logging residue of first rotation Acacia mangium in Musi Hutan Persada Ltd.Co. Proceedings of seminar "Environment Conservation Through Efficiency Utilization of Forest Biomass. p.: 155-160. DEBUT Press, Jogjakarta.

Browning, B.L. 1967. Methods of Wood Chemistry volume I. Interscience Publishers. John Wiley \& Sons, Inc., New York. 384 p.

Djarwanto, S. Suprapti dan D. Martono. 2007. Teknik perbanyakan skala kecil fungi pelapuk putih dan uji coba pemanfaatannya sebagai aktivator dekomposisi ranting dan daun mangium dan ekaliptus. Laporan Hasil Penelitian Pusat Penelitian dan Pengembangan Hasil Hutan tahun 2006. Tidak dipublikasikan.

Fengel, D. and G. Wegener. 1984. WOOD: Chemistry, Ultrastructure, Reactions. Walter de Gruyter \& Co., Berlin. 729 p.

Gunadi, D.H. 1996. Composting of agroindustrial wastes. 21 p. Indonesian Biotechnology Research Institute for Estate Crops. Bogor.

Jackson, M.L. 1958. Soil Chemical Analysis. Prentice-Hall Inc. Englewood Cliffs. New Jersey. $498 \mathrm{p}$.

Komarayati, K. dan R.A. Pasaribu. 2005. Pembuatan pupuk organik dari limbah padat industri kertas. Jurnal Penelitian Hasil Hutan 23(1): 35-41. Pusat Penelitian dan Pengembangan Teknologi Hasil Hutan. Bogor.

Mindawati, N., M.H.L. Tata, Y. Sumarna, dan A.S. Kosasih. 1998. Pengaruh beberapa macam limbah organik terhadap mutu dan proses pengomposan dengan bantuan efektif 
mikroorganisme 4 (EM-4). Buletin Penelitian Hutan No. 614: 29-46. Pusat Penelitian dan Pengembangan Hutan dan Konservasi Alam. Bogor.

Muladi, S., R. Amirta, E.T. Arung and Z. Arifin. 2001. Chemical component analysis of wood bark compost on waste of medium density fiberboard industry. Proceedings of seminar "Environment Conservation Through Efficiency Utilization of Forest Biomass. p.: 124-137. DEBUT Press, Jogjakarta.

Novizan. 2002. Petunjuk pemupukan yang efektif. 114 hlm. AgroMedia Pustaka. Jakarta.

Schmidt, O. 2007. Indoor wood-decay basidiomycetes: damage, causal fungi, physiology, identification and characterization, prevention and control. German Mycologycal Society and Springer. 40 p.

Piper, C.S. 1947. Soil and Plant Analysis. Interscience Publisher Inc. Incata Press. New York.

Steel, R.G.D. and J.H. Torrie. 1990. Principles and procedure of statistic. McGraw Hill Book Company. New York.

Sukmana, S. 1983. Evaluation of unit process in the composting of its waste. Fakulteit van de Landbouwwetenschafen Laboratory Voor Bodemfysica, Bodemcondionering en Tuinbouwbodemkunde. 